\title{
Introducing Teacher Mentoring in Kosovo Schools - Potential and Challenges for Sustainability
}

EdA Vula ${ }^{* 1}$, FATlume Berisha ${ }^{2}$, AND BleRIM SAQIPI ${ }^{3}$

$\approx$ This study examined the lessons learned from the introduction of a teacher mentoring culture within a teacher professional development program in selected pilot schools in Kosovo. Four mentor teachers and four mentee focus groups were involved in the open interviews, and their portfolios were examined. The important themes in terms of developing a school mentoring culture in a system that had lacked mentoring practices and is embarking on an ambitious curricular reform were identified. The study revealed that individual, collegial and institutional dimensions are critical in attempting to introduce the mentoring culture. The study concluded that mentoring is a mixed concept and is viewed as hierarchical but is, nevertheless, an important professional development tool for teachers who are facing the pressure of the reform. This formalized way, known as "Balkanization" culture, marks a critical step towards developing a collaborative school culture as the desired end point.

Keywords: mentoring, relationship, Kosovo, mentor, mentee

1 *Corresponding Author. University of Prishtina 'Hasan Prishtina', Faculty of Education, Kosovo; eda.vula@uni-pr.edu

2 University of Prishtina 'Hasan Prishtina', Faculty of Education, Kosovo

3 University of Prishtina 'Hasan Prishtina', Faculty of Education, Kosovo 


\section{Uvajanje učiteljevega mentoriranja v kosovskih šolah - možnosti in izzivi za trajnost}

Eda Vula*, FAtlume Berisha in Blerim Saqipi

$\propto$ V prispevku je predstavljena analiza izkušenj ob uvajanju kulture učiteljskega mentoriranja v programu strokovnega razvoja učiteljev v izbranih pilotnih šolah na Kosovem. V odprte intervjuje so bili vključenih štirje učitelji mentorji ter štiri fokusne skupine mentorirancev in mentorirank. Poleg tega so bili analizirani tudi njihovi portfolii. Prepoznane so bile teme, ki so pomembne za razvoj kulture mentoriranja v šolah, v katerih tovrstna praksa ni dobro razvita, se pa šole spoprijemajo $\mathrm{z}$ ambicioznimi kurikularnimi reformami. Raziskava je pokazala, da so pri uvajanju kulture mentoriranja pomembne individualna, kolegialna in institucionalna dimenzija. Sklepna ugotovitev analize je, da je mentoriranje mešan koncept, prepoznan kot hierarhičen, kljub temu pa je pomembno orodje pri profesionalnem razvoju učiteljic in učiteljev, ki se spoprijemajo s pritiski reform. Formalizirana pot, poznana kot »balkanizacijska« kultura, zaznamuje kritični korak k razvijanju sodelovalne šolske kulture, kar je želena ciljna točka.

Ključne besede: mentoriranje, odnosi, Kosovo, mentor, mentoriranec 


\section{Introduction}

In the previous two decades, mentoring practices have been used throughout the world to support school-based practices (Harrison, Dymoke, \& Pell, 2006) and teacher educational reforms (Musanti, 2004). Through the sustained mentoring program, the mentor comprehensively assists the teachers in developing teaching practices, curricula, instructional techniques, and enhancement of their reflections on their work (Woosley \& Tiarks, 2003). Moreover, the mentoring process is used to help build a strong professional culture of teaching and learning, while simultaneously improving the classroom teaching practices of all the teachers in the school (Hargreaves \& Fullan, 2000). Through mentoring, special attention is also given to the student learning and outcomes reached (Mathur, Gehrke, \& Hee Kim, 2012).

One of the greatest benefits of the mentors is the enhancement of the mentees' reflective practices, which helps them develop responsibilities, and build skills and self-confidence (Mathur, Gehrke, \& Hee Kim, 2012). According to Hargreaves and Fullan (2000), mentors benefit from mentees by building new insights into their teaching, new relationships, enthusiasm, and commitments. Additionally, the mentorship experience within the school influences the improvement of the mentees classroom knowledge, their assessment, and reflective practices, and school-based practices in general (Fletcher \& Strong, 2009; Mathur, Gehrke, \& Hee Kim, 2012; Stanulis \& Floden, 2009). Furthermore, Jewell (2007) and Hudson (2010) argue that besides the benefits on the personal and professional levels of the teachers as professional educators, the mentoring process positively influences the mentors and mentees relationships and collaborations toward solutions to work-related issues.

The traditional view of collegial teacher relationships reflects a school culture that Hargreaves portrayed as "Balkanization" (1994). In a Balkanized school culture, teachers work in sub-groups, insulated from each other, within the school community. Examples of such subgroups are secondary school subject departments, special needs units, or junior and primary divisions within the elementary school (Hergreaves, 1994). Each group has clear frames around its professional knowledge and status, content goals, instructional processes and assessment practices. Counteracting the Balkanized culture of collegial relationships and teacher individualism, Hargreaves defined the collaborative school culture as a critical factor in developing schools as organizations that are committed to continuous development and student learning (Hergreaves, 1994). Moving towards a collaborative school culture implies the needs to change the top-down culture of school functioning and adopting a school culture oriented 
towards continuous development and change, whereby the school community believes in a shared vision.

At the beginning of the $21^{\text {st }}$ century, Kosovo, the newest state of Europe, is undergoing major education reform movements. A history of fragmented teacher education has led Kosovo teachers entering their profession with different skills, strengths, and expectations. They are responsible for creating a sustainable knowledge-based society, human values, skills, and capacities for survival and success in the context of globalization. Additionally, they find themselves facing increased demands on the way they should shape their teaching practices. Consequently, the need for the professional development of the teaching profession arises constantly and is deemed to be a tool for helping teachers cope with the challenges of their teaching practices in a post-modern reality.

School autonomy in Kosovo has been decreasing in the last two decades. Examples of this are numerous and mostly they are not of a professional nature. The reasons for the reduction of school autonomy in the post-war Kosovo were of a political nature. The centralization of the educational management processes was seen as a tool to increase the control, as well as a way of monitoring, by the central authorities. Schools in Kosovo over the last two decades were faced with situations of prescribed curricula, receiving detailed standards and instructions as to what teaching should look like in the classroom and the decreasing need to undertake any development activity at the school level. Teacher professional development has been an activity driven by the state and provided on ad hoc bases, largely dependent on external project funding. Under such a context, mentoring practices in Kosovo schools have not been seen as any formal or informal expectation by the school community and education administrators. This situation started to change in 2008 when new legislation devolved education competencies from the central to the municipal and school levels.

In August 2011, the Ministry of Education, Science, and Technology (MEST) in Kosovo adopted a new Kosovo Curriculum Framework (KCF), which is considered to be an advanced and ambitious policy document requiring teachers to teach in ways they had not been taught before. KCF demands a competency-based approach to teaching, learning and assessment, and as such it will be an important contextual factor in the teacher development context in Kosovo in the coming years. Furthermore, the KCF provides that subject curricula be developed at the school level by teachers, implying the need for development activities at the school level as well as the need for advanced teacher skills. Of course, the success depends on how teachers perceive the change of the curriculum and how well the teachers are prepared to act as change agents and develop professionally to respond to the demands for new professionalism. 
The mentoring practices that are examined in this study were introduced to school teachers as part of a teacher professional development program to aid the successful implementation of the education innovations in Kosovo.

\section{Mentoring program in the context of Kosovo}

As part of the implementation of the teacher licensing system and in light of upgrading teacher skills to implement the new curriculum, Kosovo teachers have had numerous opportunities for professional development. Such teacher development opportunities have been mostly donor-led and project-based. The European Commission IPA 2009 "Teacher Training and Capacity Building of Municipalities and School Directors in Kosovo" Project, in collaboration with MEST, has been one of the teacher training providers in the period of 20122014. The goal of the project has been to establish a system for professional development for all teachers in pre-university education. Furthermore, the project goal was to increase the collaborations between teachers, which would later contribute positively to an enhanced collaborative culture in Kosovo schools and result in an improved student learning experience. To date, the professional development activities of this project provided a comprehensive program for teacher learning opportunities, among which the teachers were introduced to the mentoring module. All of the teachers were introduced to it, while selected teachers were exposed to more in-depth training so that they can play the role of school mentor for their colleagues.

In Figure 1, a more detailed plan of the mentoring program is elaborated. Before introducing mentors and mentees to the four other modules targeting the skills development for the new curriculum implementation, the mentees and the mentors were introduced to the mentoring module in a workshop format with the purpose of developing collaborative structures and processes among teacher colleagues. Following the workshops, mentors received help in developing mentoring activities, starting with the identification of basic to specific needs, through the design of action plans and on-going reflective activities. The process was carefully monitored and recorded. 


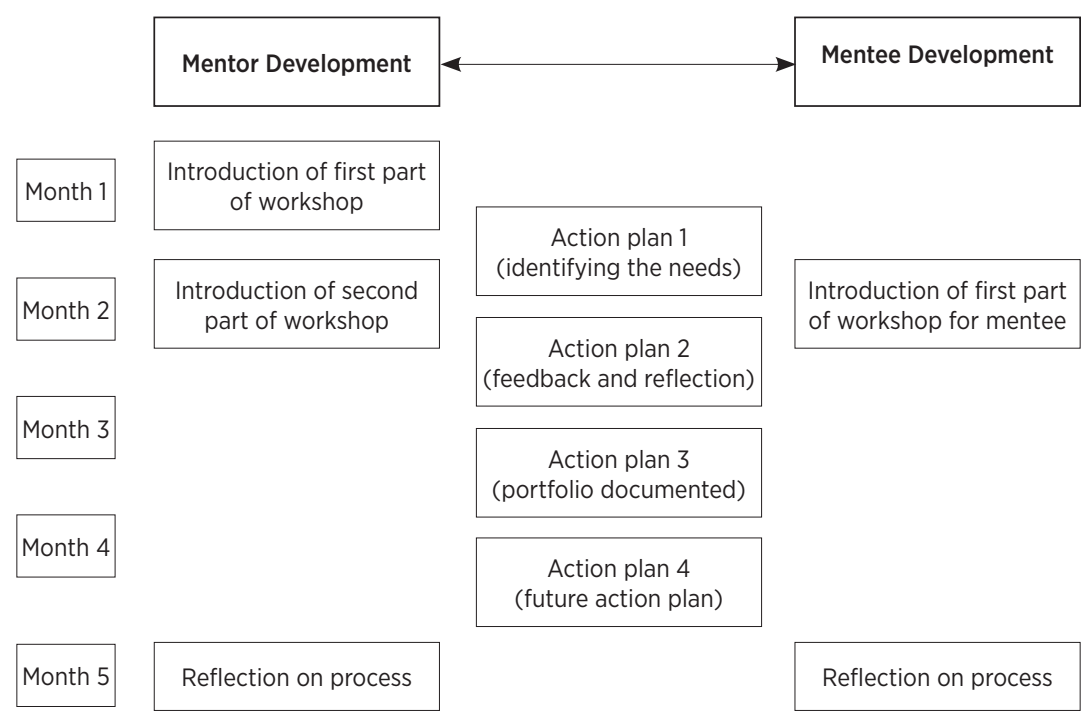

Figure 1. The mentoring module within the in-service training program

\section{Methodology}

This study examines the mentoring implementation process as part of the professional development program. The study focused specifically on the monitoring of the program in one gymnasium (academic secondary school) and one vocational education training (VET) secondary school in the municipality of Drenas. From the gymnasium, a total of 12 teacher participants (from which three female and nine male) were trained to play the role of a mentor, from a total of 78 teachers who, in addition to the mentoring module were also introduced to four other modules of the professional development program. Similarly, 16 VET teachers were mentors (seven female and nine male) and a total of 101 teachers were participating in the program. The data was collected in the field during the training process, mainly interviews with four mentors (two from each school) and two mentee focus groups (one from each school, a total of eight mentee teachers from the gymnasium and nine mentee teachers from the VET), and portfolios on which the mentors reflected throughout their activities. The interviews were facilitated by trainee members (workshop facilitators) and the authors of this paper. The interview questions were openended with the focus on the mentor and mentees' perceptions of the role of the mentoring program, the relationships and the collaborations between mentor and mentee and their reflective practices. The portfolios were designed as directed by the module trainees, with the focus on reflective writing on meetings 
between mentor and their group of mentees. The data was collected over a period of six months. The four mentors for the study were randomly selected (two from each school), whereas the focus groups were the mentees of the selected mentors participating in the study, there were a total of 17 mentees. It is worth noting that all of the teachers participating in this study were subject teachers. Six of the gymnasium mentor teachers had experience in teaching for more than 13 years, four mentors had 9 to 13 years, and two mentor teachers had 4 to 8 years of experience. The VET school teachers had four mentors with more than 13 years of experience in teaching; two mentors 9 to 13 years, and ten mentors had 4 to 8 years of teaching experience.

Qualitative phenomenological data analysis was used. The approach to data analysis utilized the principles of content analysis. The process of data analysis included selecting, highlighting, and identifying the similar statements, phrases or words in the participants' records (portfolio) and in their interview transcripts. After the initial coding, the data was categorized into specific themes:

1. Mentoring, and the role of the mentors and mentees;

2. Mentoring and professional collaboration between colleagues; and

3. Mentoring and reflection.

\section{Findings}

\section{Mentoring and the role of the mentors and mentees}

Wildman et al. (1992) emphasized that because mentoring is practiced in different circumstances at different schools, and because it involves personal interactions, "the role of mentoring cannot be rigidly specified". To the teachers of Kosovo, in the research setting, mentoring was a new concept. Most of the participants (mentors and mentees) of our study, in the beginning, saw mentoring as a process through which selected teachers were allowed to evaluate or criticize their teaching practices. Furthermore, the mentees were dejected about the fact that someone would visit them in the classroom while teaching. They saw the role of the mentor as an "inspector" who should assess their teaching practices and their communication skills with the students. One mentee from our focus group interviews expressed himself this way:

At the beginning, the mentor's presence in my classroom bothered me. With my pupils, I am used to feeling like a family, and of course also the pupils are not free to express themselves as usual. Mentee (m)1 Focus Group (fg) 1 
Anyone who comes in the classroom, either observing or teaching, even if a pupil enters the classroom, it triggers tensions - there will be emotions on both sides. m2fg1

In contrast, the mentors also express their difficulties and their discomfort with their role as a mentor.

I have been working for 13 years in this school, and I have never attended a teaching classroom of my colleagues. I feel even more uncomfortable and disfavoured when thinking that my colleagues may think that I will misuse the process of mentoring. Mentor 2

Both the mentors and the mentees had difficulties accepting the mentoring process in their school. According to the participants, as a new approach, mentoring will take time and effort to be effectively applied in the school context. Moreover, it was seen that even though the mentors were capable and willing to work together with their colleagues-mentees, in some cases there were arguments between them, especially from teachers who consider themselves to be more experienced than their colleague-mentors.

When both the mentor and the mentee were asked to explain what they believe the mentors' role is, one experienced mentee teacher related the mentor's role only with "scientific" and "academic" knowledge:

The mentor must be better than I am professionally; he or she must have more academic knowledge. They must be better prepared than us, the mentees. m3fg1

The obviously noticed misunderstanding of the mentor's role was seen as a trigger for the mentors of our study, to try to change their behaviour and communication style with their mentees. After a few meetings, the mentors had with each other, and also the mentors with their group of mentees, there was much discussion on identifying the problems in their everyday teaching. Furthermore, they discussed the best solutions to solving the problem. This approach was a great step forward in easing the process of mentoring. Through sincere conversations, testing prejudgments, and searching out meanings, the mentors and the mentees as teachers become more critical in understanding their role (Jewell, 2007):

Every teacher must perform his/her work with dedication and professionalism. My colleagues and I should always be aware that in front of ourselves we have the pupils always observing us, who examine and value our daily commitments. Therefore, as mentors, it is our obligation to invite young teachers and also older colleagues to observe our classes so that we encourage them to be more demanding and engaging -so that we all learn together throughout our careers and to evaluate our work. Mentor 3 
The mentors in our study claim that the mentoring process had a positive effect on their practices. Most of them observe a certain acceptance and respect for their work, and they say that they benefit from their role as a mentor in many aspects:

I have benefited a lot from working with the colleague mentees that I have in my group. Some of the benefits are: sharing of the experiences from my work; the building of self-confidence; progression of group work; I became a better planner, more sociable, and also I can notice that now I constantly reflect on my work. Mentor 4

Both the mentors and their mentees of our study agree that the mentor's role, first of all, is to be a good friend, a facilitator, a supporter and someone that guides their colleagues. Additionally, they thought that the efficacy of mentoring is linked to the amount of time that the mentor and mentee work together and to the number of mentees involved for one mentor (Jewell, 2007). However, the main factor in the success of the mentoring process that was mentioned most frequently was the collaboration and learning from each other.

\section{Mentoring and professional collaboration between colleagues}

According to Musanti (2004), in many in-service professional development mentoring programs, the teacher plays a collaborative role. In our study, we find that mentoring is used as a tool for collaboration between colleagues. Immediately following the second workshop, we noticed that there was more flexibility in the communication between mentors and mentees. Mentoring has benefits specifically for the mentors (Banks, 2010), because in serving as a mentor, many skills were developed, such as collaboration, effective communication, planning, problem solving, and other factors. Researchers promote mentoring as a force for change to diminish isolation and promote teacher collaboration (Semeniuk \& Worrall, 200o). "Integrating a mentoring and collaborative teacher role in a professional development program requires the construction of a network of interactions instead of the traditional dyadic relationship ascribed to mentoring role" (Musanti, 2004).

From the beginning, I have communicated softly with the teachers, I changed the misperception that I was going to be the one telling them what to do and will be the one creating the decision file in regards to their licensing or not. We clearly agreed that our mission here was to collaborate and find better ways of teaching and working with pupils. Mentor 1

Building the relationship between mentors and mentees is the most important skill for the success of the mentoring process. Effective mentoring 
depends on the affectivity of the "joint work" of the mentor and the mentee (Fischer \& Andel, 2002). Thus, during the mentoring program, the mentors and mentees worked together on curriculum planning, classroom management, and on assessment procedures. One of the mentors writes in his portfolio: In the second phase, we started with the classroom observations, and then together we analysed what went well and what not. One of the teachers had asked me for advice on the drafting of a test. After we jointly prepared the test, we noticed positive changes in pupils' performance in it. I believe that the strongest part of this process is, indeed, the good and open communication between us. Mentor 3

One of the teaching weaknesses in the most of the schools in Kosovo is the orientation towards the theoretical aspect of teaching. One reason for this is the lack of laboratories in schools, the lack of teaching materials, and in most cases it is because of the gaps in the necessary pedagogical preparations of the staff. In his portfolio, a mentor describes how he discusses ways to bridge the gap between theory and practice with his group of mentees:

Together with the teachers of my group, we have a plan for making video recordings that will help us to at least visually present experiments that we do not perform in the school in the absence of laboratories. Additionally, we discussed implementing the project work and other similar activities in our teaching that we were introduced to in Module 3 so that the pupils use the Internet for learning purposes and not only wasting their time on Facebook. Mentor 3

Collaboration within schools, however, is essentially an interdependent relationship based on mutuality and a shared task (Musanti, 2004). First of all, school-based mentoring has enabled teachers to admit that positive changes happen only if they share thoughts and tasks related to education with each other:

In the past, we always talked about politics and sport. Now we talk about our educational activities. m3fg2

\section{Mentoring and reflection}

The educational reform, in general, does not have to follow the same predetermined linear scheme. In fact, educational transformations are related to the reflective thinking of both mentors and mentees. They develop their own thinking about their own practices with the aim of changing it according to students' needs (Galea, 2012). Thus, Donald Schon's theory of the teacher as a "reflective practitioner" can formally be established in the mentoring relationship (Fischer \& Andel, 2002). 
To examine the importance of reflection in the mentoring process, in this study, we analysed the reflections from their meetings held with their group of mentees, recorded in the portfolios of mentors. From the analysis of the portfolios, we found that teachers generally appreciate mentoring as a process. They believe that mentoring enables them to reflect on their work while simultaneously giving them the opportunity to discuss the possibility of resolving difficulties with the colleagues. Through critical reflection, teachers change their attitudes and develop new skills to advance the work of their students. Furthermore, during their reflective practices with their colleagues, they develop proposals to improve their teaching strategies.

Part of the process of 'reflection on practice' involves exposing the mentor's notice to his/her mentees. This is a form of validation in which a teacher's world of personal experiences is set alongside the world of a professional colleague's experiences (Harrison, Lawson, \& Wortley, 2005).

One of the mentees was able to make a new decision about an assessment approach for his students after several meetings with his mentor. His reflection was expressed in this way:

The suggestions I received from my mentor in regards to the design of test assessment in chemistry were very helpful. The changes in the way the questions were developed/ designed made my students have better results in the test. I realized that if we want to assess objectively the students' levels of achievement, first we must pose correct, accurate and understandable questions. $\mathrm{m} 4 \mathrm{fg} 2$

As a result of regular meetings, the mentors and mentees engaged in the reflective processes for making more effective cooperation and sharing experiences. However, according to the participants, experience was not seen as the most important factor for the success in their teaching. In the school-based mentoring process, there were participants with greater experience and with superior qualifications in the role of the mentees and not as a mentor, yet they were good examples of lifelong learners. They are also very much engaged in the mentoring process, and their reflection and cooperation are crucial to the success in their professional development.

I have published many scientific papers in the field of physics, and I continue to pay attention to scientific achievement on the local and international levels. However, students require teachers who implement pragmatic teaching activities in the classroom, and allow them to use their knowledge in everyday life. I try to do this, and the possibility of collaboration with colleagues to find the best forms of teaching is quite necessary. $\mathrm{m}_{5} \mathrm{fg}_{2}$ 
I have been an English teacher for 12 years. Over these years, I have used various methods of teaching that I have constantly analysed and reflected on if they brought results that I wanted. I can freely say that "experience is the best teacher"; however, I need to be assessed by others as well, the mentor or a colleague, so that also I take their suggestions since self-assessment is not enough to enable me to reach/fulfil my long-term goals completely. mifg 2

One of the most common activities during the program was the observation, which in the beginning, was the main parameter used by the mentors and was often identified with the mentoring process. Mentors used a checklist to assess the mentees' teaching based on their needs discussed before observation. The observation was then followed by reflection from the both of them. The systematic discussion helped the reflection as a very important process within mentoring, which is a form of action-oriented inquiry, and it provides products that can be changes in practice (Harrison, Lawson, \& Wortley, 2005). Critical conversations, reflections, and action are part of the mentoring. Such activities seemed to permit more opportunities for 'constructing' practice by both mentor and mentee, thereby increasing the opportunities for developing critical reflections on practice overall and engaging in the deeply reflective processes that are crucial to successful mentoring and professional growth (Harrison, Lawson, \& Wortley, 2005; McCrary \& Mazur, 2010).

\section{Discussion and Recommendations}

The aim of the mentoring program described in this paper was twofold: to develop school-based mentor's skills, and at the same time to encourage the collaboration between mentors and mentees in advancing the implementation of the modules offered by the in-service teacher development program. Even though mentoring is mostly defined as a practice that legitimizes the "best teachers" as mentors who are assumed to possess the "best practices" and authorized knowledge (Musanti, 2004), this study demonstrates that schoolbased mentoring needs to be seen as a process rather than an event (Abiddin \& Hassan, 2012) with scheduled and regular meetings between mentors and mentees based primarily on peer collaboration. Based on the findings of this study, collaboration was the most significant value of the mentoring program. The participants believed that mentoring should be a process in which all teachers share understandings and values. Moreover, mentoring concerns the whole school (Sundli, 2007). The introduction of mentoring processes in schools isolated within a professional development program seems to be a good 
start; however, this imposes restrictions on developing mentoring as a school culture feature that occurs on an on-going basis and mutual and peer relationships. Due to the immediate need for the adaptation of teachers to the new Kosovo Curriculum Framework, the policy documents require the planning of school activities, the professional development of teachers, as well as the strategic planning to be conducted within the school. As a result, the Ministry of Education, Science and Technology is constantly working toward the institutionalization of the process of the mentoring program, which is greatly supported by the municipality education leaders and school directors.

The design of this mentoring program in Kosovo embedded within itself certain features of hierarchical relationships between the mentor and mentee; therefore, it led to a confusion of mentoring and monitoring concepts among the teachers involved. The perception of mentoring within the monitoring framework appears to be a normal reaction given the traditional monitoring culture that had been embedded in Kosovo schools, within either school director mentoring of teaching quality or external monitoring that was coming either from municipal authorities or central ones.

Further development of mentoring processes in Kosovo schools should be resourced by addressing the personal, collegial, and institutional dimensions within which it is embedded, summarized in Table 1 . These dimensions were of a dynamic nature and interacting during the piloting phase, very often resulting in tensions. It is critical that introducing the mentoring process in schools should be linked with the education policies and broader developments, such as introducing new curricula, while the personal, collegial and institutional dimensions are addressed in parallel and not consecutively.

Table 1. The developing of sustainable mentoring culture in schools

\begin{tabular}{lll}
\hline Personal dimension & Collegial dimension & Institutional dimension \\
\hline $\begin{array}{ll}\text { Perception of mentoring } \\
\text { mixed with monitoring ele- }\end{array}$ & $\begin{array}{l}\text { Limited collegial collaboration } \\
\text { in the past }\end{array}$ & $\begin{array}{l}\text { Weak school culture; } \\
\text { Unstructured provision of } \\
\text { mentoring process; } \\
\text { Viewing mentoring as expert } \\
\text { job }\end{array}$ \\
$\qquad \begin{array}{ll}\text { Weak links with education } \\
\text { development processes }\end{array}$ \\
$\begin{array}{ll}\text { School structures embedding mentoring within its culture, by } \\
\text { moving teachers to better understanding of mentoring concept }\end{array}$ \\
\hline
\end{tabular}


Most mentors and mentees were very enthusiastic to do the activities in their classrooms as a result of the mentoring process; however, others most appreciated the reflective writing of, in most cases more about general aspects of their professional tasks and the relationship between them, than for any specific situations related to other programs on teaching or assessment that were offered within the program. This discontinuity between mentoring and the other modules was related to the small amount of time for doing all the activities within the program. Mentors were responsible to learn and share experiences at the same time, and to plan the meetings with mentees. Thus, they could not manage the time to examine and reflect on their actions. We also found some confusion about the role of the school-based mentors. Some of them identified mentoring more as an observation of their mentees in their classrooms, and also a lack of understanding how to relate their work to the modules as a whole.

There is a need for more collaboration between schools and universities. The teachers express their need to have regular meetings with educational experts, because the mentoring of experienced teachers requires more knowledge on theory and teaching practices. All participants in our study, even those who are experienced teachers, agreed that they need mentoring, as a lifelong learning process and as a form of continuous professional development. The findings of this study provide insights that more emphasis should be placed on the preparation of mentors to support their colleagues, even them those are experienced teachers during the implementation of new modules and educational reform. This preparation work should be aimed at developing structures, mechanisms and a culture of peer mentoring at the school level. Therefore, the mentoring program which is being developed will be a critical step towards establishing a real peer mentoring and collaborative culture practices.

\section{Acknowledgments}

The authors acknowledge the support by the GIZ European Commission IPA 2009 the "Teacher Training and Capacity Building of Municipalities and School Directors in Kosovo" project and the Ministry of Education, Science and Technology. The authors are grateful and thankful to all teacher participants of this study, and their hospitality during the school visits

\section{References}


Banks, H. K. (2010). A qualitative investigation of mentor experiences in a service learning course.

Educational Horizons, 89(1), 68-79.

Fischer, D., \& Andel, L. (2002). Mentoring in teacher education - toward innovative school

development. 27th annual conference of ATEE. Warsaw. Retrieved from http://www.mint-mentor.net/ en/pdf/Papers_fischerAndel.pdf

Fletcher, S., \& Strong, M. (2009). Full-release and site-based mentoring of new elementary grade teachers: an analysis of changes in student achievement. New Educator, 5, 329-341.

Galea, S. (2012). Reflecting reflective practice. Educational Philosophy and Theory, 44(3), 245-258.

Hargreaves, A., \& Fullan, M. (2000). Mentoring in the new millennium. Theory into Practice, 39(1), 50-56.

Harrison, J., Dymoke, S., \& Pell, T. (2006). Mentoring beginning teachers in secondary schools: an analysis of practice. Teaching and Teacher Education, 22, 1055-1067.

Harrison, J., Lawson, T., \& Wortley, A. (2005). Facilitating the professional learning of new teachers through critical reflection on practice during mentoring meetings. European Journal of Teacher Education, 28(3), 267-292.

Hergreaves, A. (1994). Changing teachers, changing times: Teachers' work and culture in the postmodern age. New York: Teachers College Press.

Hudson, P. (2010). Mentors report on their own mentoring practices. Australian Journal of Teacher Education, 35(7), 30-42.

Jewell, M. (2007). What does mentoring mean to experienced teachers? A phenomenological interview study. Teacher Educator, 42, 289-303.

Mathur, S. R., Gehrke, R., \& Hee Kim, S. (2012). Impact of teacher mentorship program on mentors' and mentees' perception of classroom practices and the mentoring experience. Assessment for Effective Intervention, 38(3), 154-162.

McCrary, E. N., \& Mazur, M. J. (2010). Conceptualizing a narrative simulation to promote dialogic reflection: using a multiple outcome design to engage teacher mentors. Educational Technology Research \& Development, 58, 325-342.

Musanti, S. I. (2004). Balancing mentoring and collaboration. Curriculum and Teaching Dialogue, 6(1), 13-23.

Semeniuk, A., \& Worrall, M. A. (2000). Rereading the dominant narrative of mentoring. Curriculum Inquiry, $30(4), 405-428$.

Stanulis, R., \& Floden, R. (2009). Intensive mentoring as a way to help beginning teachers develop balanced instruction. Journal of Teacher Education, 60, 112-122.

Sundli, L. (2007). Mentoring - a new mantra for education? Teaching and Teacher Education, 23, 201-214.

Wildman, T. M., Magliaro, S. G., Niles, R. A., \& Niles, J. A. (1992). Teacher Mentoring: an analysis of roles, activities, and conditions. Journal of Teacher Education, 43(3), 205-213.

Woosley, T., \& Tiarks, C. (2003). Induction programs, when integrated with mentoring are advantageous. American Secondary Education, 28(3), 3-12. 


\section{Biographical note}

Dr. EDA Vula is an associate professor for didactics of mathematics and action research at the Faculty of Education, University of Prishtina in Kosovo. She is interested in teacher training and mathematics education with a focus on collaborative action research. In addition to the publication of scientific papers in the field of educational sciences, she has also published professional papers related to teacher training for pre and in service teachers. She has also engaged in many EU projects and has offered her expertise in consultancy for several international and national training programs for teacher professional development.

Dr. FATLUme Berisha is a teaching assistant/ lecturer at the Faculty of Education, University of Prishtina. She has been teaching different science education related courses. Her research interests include teacher education, student interest and motivation in science education, sustainable science education and environmental education. She strives to promote inquiry based science education and global thinking in the teacher education practices.

Dr. Blerim SAqIPI is a staff member of the University of Prishtina's Faculty of Education in Kosovo. He teaches courses on educational research, educational change and teacher professional development. His research interest centers around the understanding of the social and educational context of developing teacher professionalism and teacher education policy. 